\title{
Lip and Oral Cavity Cancer Pathologic Distant Metastasis TNM Finding v7
}

National Cancer Institute

\section{Source}

National Cancer Institute. Lip and Oral Cavity Cancer Pathologic Distant Metastasis TNM

Finding v7. NCI Thesaurus. Code C88953.

A pathologic finding about one or more characteristics of lip and oral cavity cancer,

following the rules of the TNM AJCC V7 classification system as they pertain to distant

metastases. There is no pathologic M0 for lip and oral cavity cancer. 